\title{
Nagy adatbázisok neurológiai kórképekben: nemzetközi áttekintés a sclerosis multiplex példáján
}

\author{
Iljicsov Anna dr. ${ }^{1}$ - Simó Magdolna dr. ${ }^{1}$ - Tegze Nárcisz dr. ${ }^{1}$ \\ Szócska Miklós dr. ${ }^{2}$ - Mátyus Péter dr. ${ }^{2}$ - Bereczki Dániel dr. ${ }^{1}$ \\ 'Semmelweis Egyetem, Általános Orvostudományi Kar, Neurológiai Klinika, Budapest \\ ${ }^{2}$ Semmelweis Egyetem, Egészségügyi Közszolgálati Kar, Digitális Egészségtudományi Intézet, Budapest
}

\begin{abstract}
A rutin-betegellátás során hatalmas adattömeg keletkezik, amelyet jelenleg elszórva, többféle informatikai és papíralapú rendszerben tárolnak az egészségügyi intézményekben. A nagy adatbázisok elemzése egy adott betegség vonatkozásában segít egy populáció egészségügyi szükségleteinek meghatározásában és egészségügyi ellátásuk megszervezésében. Modellként a sclerosis multiplexet $(\mathrm{SM})$ választottuk, melynek jól meghatározott diagnosztikus kritériumai vannak; a kezdeti diagnózis általában fekvőbeteg-ellátó intézményben történik, és a betegek gondozása és követése a járóbeteg-ellátásban zajlik. A sclerosis multiplex példáján célunk a nemzetközi és hazai adatbázisok feltérképezése és elemzése. A Semmelweis Egyetemen induló adattófejlesztés elemeként célnak tűztük ki a betegségspecifikus adatbázisok szükséges jellemzőinek meghatározását. A lényeges adatbeviteli kritériumok meghatározása céljából áttekintjük a legfontosabb nemzetközi SM-adatbázisokat. Vizsgáljuk a rögzített adatokat, az adatbázisok struktúráját, kitérünk az adatvédelmi szempontokra, az egyes adatbázisok hozzáférhetőségére és alkalmazási lehetőségeire. A SM helyi adatbázisok kezdetben elsősorban a betegek hatékonyabb gondozását célozták. Következő lépésként helyi és nemzetközi tudományos kutatásokhoz is szükség volt a betegek adataira. A betegségspecifikus adatbázisok létrehozása nagy jelentőségú volt a finanszírozók számára is, és a nagy betegpopulációról szerzett hosszú távú információk (úgynevezett „real-world” adatok) rendkívül fontosak a készítmények hatékonyságának és mellékhatásainak pontosabb megítélésére a populáció szintjén. Elemzésünk hozzájárul egy egészségügyi intézményi „adattó” létrehozásának szempontjaira fókuszáló projekthez, melyben a Semmelweis Egyetem egyes klinikái és diagnosztikus egységei mellett a Digitális Egészségtudományi Intézet is részt vesz.
\end{abstract}

Orv Hetil. 2019; 160(4): 123-130.

Kulcsszavak: sclerosis multiplex, regiszter, adatbázis, big data, adattó

\section{Databases in neurological diseases: overview of international examples in multiple sclerosis}

\begin{abstract}
Vast amounts of data are created during routine patient care which are stored in unstructured digital and hardcopy formats in healthcare institutions. Analysis of large databases help to define the healthcare needs of the population and to organize healthcare services for specific diseases. As a model, we selected multiple sclerosis (MS), a disease with well-defined diagnostic criteria, a usually inpatient initial diagnosis, and a need for regular outpatient check-up. Using multiple sclerosis as an example, we set forth to screen and analyze international and Hungarian databases. In the framework of the initiation of the data lake system of Semmelweis University, we aim to define features of the data system needed for disease-specific databases for future applications. To determine essential data-entry criteria for such a database, we review the most important multiple sclerosis registries. We evaluate the type of registered data, structure of database, privacy issues, the availability and ways of application of the databases. Initially, the MS databases were created locally, aiming for better care of patients. As a further step, data were collected for scientific research by national and international co-operations. Disease-specific databases have become of high priority for national healthcare providers, and long-term information on a population ("real-world" data) is extremely important to assess the effectivity and safety of a treatment at the population level. Our analysis contributes to a project which focuses on the aspects of developing a data lake at a service provider level including clinical, diagnostic and digital healthcare departments of Semmelweis University, Budapest, Hungary.
\end{abstract}


Keywords: multiple sclerosis, registry, database, big data, data lake

Iljicsov A, Simó M, Tegze N, Szócska M, Mátyus P, Bereczki D. [Databases in neurological diseases: overview of international examples in multiple sclerosis]. Orv Hetil. 2019; 160(4): 123-130.

(Beérkezett: 2018. augusztus 8.; elfogadva: 2018. szeptember 9.)

\section{A Szerkesztőség felkérésére készített tanulmány.}

\begin{abstract}
Rövidítések
BNO = betegségek nemzetközi osztályozása; CRO $=($ Contract Research Organisation) Szerződéses Kutatási Szervezet; DMSTR $=($ Danish Multiple Sclerosis Treatment Register $)$ Dán SM Regiszter; EDMUS = (European Database System for Multiple Sclerosis $)$ Európai SM Adatbázis; EDSS = (Expanded Disability Status Scale) Bővített Rokkantsági Állapot Skála; EUReMS = (European Register for Multiple Sclerosis) Európai SM Regiszter; iMED = (Innovation Medicine Program) Innovációs Orvostudományi Program; MSBase $=$ (multiple sclerosis base) sclerosis multiplex bázis; NARCOMS $=($ North American Research Consortium on Multiple Sclerosis) Északamerikai SM Kutatási Konzorcium; OFSEP $=$ (Observatoire Français de la Sclérose en Plaques) Francia SM-figyelö Prog$\mathrm{ram} ; \mathrm{SM} / \mathrm{MS}=$ (multiple sclerosis) sclerosis multiplex; TUKEB = Tudományos és Kutatásetikai Bizottság
\end{abstract}

A rutin-betegellátás során egy betegről is számos adat (többek között klinikai, laboratóriumi, képalkotó) keletkezik, amelyek archiválása egyrészt jogszabályi előírás, másrészt feldolgozásukkal orvostudományi, epidemiológiai, egészséggazdasági kérdésekre kaphatunk választ, így az ilyen adatbázisok és regiszterek jelentős erőforrást képviselnek. A feldolgozás előfeltétele azonban az adatok strukturált rögzítése és azok naprakész frissítése, ami célzott és részletes regiszterek kiépítését teszi lehetővé. Ezt a sclerosis multiplex példáján mutatjuk be. A neurológiai betegségek közül első lépésben a sclerosis multiplexre (SM) egyrészt azért esett a választás, mert a Magyar Neuroimmunológiai Társaság egységes, országos sclerosis multiplex regiszter létrehozását tűzte ki célul, így ez aktuális kérdés. Másik szempont a gyakorlati kivitelezhetôség, ami a SM esetében jobb, mint egyéb neurológiai betegségek esetében, ugyanis a betegek ellátása centrumokba szervezett, létszámuk alacsonyabb, továbbá egyetlen BNO-kód tartozik a kórképhez (G35).

A rokkantság hátterében a leggyakrabban idegrendszeri betegségek állnak, és ezek a kórképek a második leggyakoribb halálokként szerepelnek, világszerte a halálesetek egyhatodát okozva [1]. A neurológiai betegségben szenvedők száma Európában nő: míg 2004-ben 127 millió, 2010-ben már 178 millió európai polgárt érintett valamilyen idegrendszeri betegség [2]. Ezen időszak alatt a sclerosis multiplexben szenvedők száma is nőtt Európában: 380 ezerról 540 ezerre. A betegség éves költségei ez idő alatt még nagyobb ütemben emelkedtek: európai szinten 8,8 milliárd euróról 14,6 milliárdra. Az egy betegre jutó költségek vonatkozásában a sclerosis multiplex a neurológiai betegségek közül a neuromuscularis betegségek után a második helyen szerepel. Gustavsson és mtsai szisztematikus összefoglalója a magyarországi sclerosis multiplexes betegek számát 6200-ra becsüli, és Magyarországon a vizsgált 12 idegrendszeri betegségcsoport közül az egy betegre jutó költséget a sclerosis multiplexes betegeknél becsülik a legnagyobbra [2]. Az egész országra vonatkozó epidemiológiai felmérés sclerosis multiplexben Magyarországon még nem történt, az országosan becsült betegszám a szegedi felmérésből extrapolálható $[3,4]$, ahol a prevalencia 83,7/100 000 volt. A hazai vizsgálat egy megyére korlátozódott, az országos helyzet felmérése folyamatban van. A tisztázatlan epidemiológiai kérdésekre választ adhat egy megfelelő regiszter.

Hazánkban a sclerosis multiplexes betegek ellátásának szervezése 31 SM-centrumban történik, ez elősegíti, hogy a tervezett regiszterek lefedettsége magas legyen. E krónikus betegséggel élők rendszeresen járnak ambuláns kontrollra, ami hosszmetszeti elemzést is lehetővé tesz. A centrumok egyrészt helyi adatbázisokat hoznak létre saját betegeik követése céljából, másrészt, a szegedi regiszterből kiindulva, jelenleg zajlik az egységes országos SM-regiszter kiépítése [5]. A helyi adatbázisok fejlesztésén és az országos regiszter kiépítésén túl fontos lehet nemzetközi SM-regiszterekhez történő csatlakozás, hogy a magyarországi adatok közvetlenül is integrálódhassanak a nemzetközi kutatásokba.

Jelen munkánkban áttekintjük a mintának tartható legnagyobb SM-adatbázisokat. Célunk egyrészt a nemzetközi és a hazai adatbázisok feltérképezése és elemzése, kitérve a rögzített adatokra, az adatbázisok struktúrájára, az adatvédelmi szempontokra, az egyes adatbázisok hozzáférhetőségére és alkalmazási lehetőségeire. Elemzésünk másrészt hozzájárul egy egészségügyi intézményi „adattó” létrehozásának szempontjaira fókuszáló projekthez, melyben a Semmelweis Egyetem egyes klinikái és diagnosztikus egységei mellett a Digitális Egészségtudományi Intézet is részt vesz. 


\section{Módszer}

\section{A nemzetközi SM-adatbázisok áttekintése}

A nemzetközi SM-adatbázisokat az interneten történő kereséssel azonosítottuk. A kereséshez egyrészt a Google Scholar (https://scholar.google.com/) adatbázist alkalmaztuk a („multiple sclerosis” AND „registry”) kulcsszavak kapcsolásával. A keresés másik forrása a MEDLINEadatbázis volt, amelyben az előző keresési stratégiát alkalmaztuk, a keresést a közlemény címére korlátozva, kiemelten a témában született összefoglaló cikkekre fókuszálva. Jelen közleményünkben nem törekedtünk teljességre, tehát az összes létező SM-adatbázis felsorolására, hanem szakmai vagy praktikus szempontok alapján kiválasztottuk azokat, amelyek ismérvei megfontolandók egy intézményi adattó alapját képező helyi adatbázis vagy országos regiszter múködtetése során. Az elemzendő adatbázisok kiválasztásakor figyelembe vettük, hogy elérhető-e róluk részletes bemutatás a nemzetközi szakirodalomban (számos országos SM-regiszternek csak a létezése ismert, struktúrája nem nyilvános), továbbá hogy a regiszter alapján születtek-e tudományos publikációk, milyen régóta múködik, és az ország SM-populációjának mekkora részét fedi le az adatbázis.

\section{Eredmények}

A SM-adatbázisok és -regiszterek nagyrészt az ipartól független, az ellátásszervezést és/vagy a tudományos kutatást szolgáló, az egészségügy finanszírozói vagy kutatási források által támogatott adatbázisok. Az adatbázi- sok másik típusa az új farmakoterápiás eljárásokkal terjedt el: a gyógyszeripar által szponzorált regiszterek általában az adott gyógyszer regisztrációját követően a posztmarketing időszak adatgyűjtését célozzák. A legfontosabb nem ipari SM-adatbázisokat az 1. táblázatban foglaljuk össze.

\section{A gyógyszeripartól független, elsősorban tudományos célú országos adatbázisok}

A SM miatt gondozott betegek adatainak regisztrálása és rendszerbe foglalása évtizedes törekvés, amelyet kezdetben elsősorban helyileg hoztak létre, és az adatbázis a betegek hatékonyabb gondozását célozta. Emellett a tudományos kutatásokhoz is szükség volt a betegek adataira, regionális, majd országos, illetve nemzetközi összefogásban gyűjtve, amelyekből korán kimutathatóvá váltak például a földrajzi különbségek a betegség előfordulásában $[6,7]$ és a genetikai faktorokra utaló családi halmozódás $[8,9]$. A SM-regiszterek helyi és regionális szinten már évtizedek óta léteznek, azonban az országos adatbázisok jelentőségét fóleg a 2000-es évektől kezdték felismerni, ezeket kiépíteni és eredményeiket publikálni. Egy közelmúltbeli összefoglaló közleményben Flachenecker és mtsai [10] 20 európai országos regisztert azonosítottak és jellemeztek, és szembetűnő heterogenitásuk miatt egységes szakmai nyelvet és irányelveket javasoltak európai szinten. Ugyanekkor, az országos SMbetegszervezetek európai ernyőszervezetének (European Multiple Sclerosis Platform [11]) kezdeményezésére és az Európai Unió forrásainak segítségével, 2011 és

1. táblázat | Sclerosis multiplex regiszterek és adatbázisok

\begin{tabular}{|c|c|c|c|c|c|}
\hline A regiszter neve & Fő finanszírozó & $\begin{array}{l}\text { Székhely, } \\
\text { az adatkezelés } \\
\text { centruma }\end{array}$ & $\begin{array}{l}\text { Az alapítás } \\
\text { éve }\end{array}$ & $\begin{array}{l}\text { Betegszám } \\
\text { (lefedettség) }\end{array}$ & Sajátosság \\
\hline Dán SM Regiszter & $\begin{array}{l}\text { Állami népegészségügyi } \\
\text { költségvetés, SM-egyesület }\end{array}$ & Koppenhága & 1956 & $>20000(91 \%)$ & $\begin{array}{l}\text { A beteg állapotának alakulását nem } \\
\text { rögzíti, egyéb állami adatbázisokkal } \\
\text { összefésülhető. }\end{array}$ \\
\hline Svéd SM Regiszter & $\begin{array}{l}\text { Állami egészségügyi } \\
\text { költségvetés }\end{array}$ & Stockholm & 2001 & $14500(80 \%)$ & $\begin{array}{l}\text { A beteg is közvetlenül hozzáférhet az } \\
\text { adataihoz, a centrumok összefoglaló } \\
\text { adatainak egy része nyilvános. }\end{array}$ \\
\hline Olasz SM Regiszter & Országos betegszervezet & Bari & 2015 & $54000(50 \%)$ & 2001-2015 MSBase-alkohorszként \\
\hline Német SM Regiszter & Országos SM-társaság & Hannover & 2001 & $48000(20 \%)$ & $\begin{array}{l}\text { Az SM-centrumi akkreditáció feltétele } \\
\text { a csatlakozás. }\end{array}$ \\
\hline $\begin{array}{l}\text { Az Egyesült Királyság } \\
\text { SM Regisztere }\end{array}$ & Országos SM-társaság & Swansea & 2014 & 17000 & A beteg is közvetlenül regisztrálhat. \\
\hline $\begin{array}{l}\text { Észak-amerikai SM } \\
\text { Kutatási Konzorcium }\end{array}$ & $\begin{array}{l}\text { SM-centrumok egyesülete, } \\
\text { országos SM-társaság }\end{array}$ & St. Louis & 1993 & 41000 & A beteg is közvetlenül regisztrálhat. \\
\hline EDMUS & $\begin{array}{l}\text { EDMUS nonprofit } \\
\text { szervezet }\end{array}$ & Lyon & 1990 & $\begin{array}{l}\text { ? nemzetközi } \\
\text { részvétel, francia } \\
\text { kohorsz } 45000 \\
(50 \%)\end{array}$ & A csatlakozásért egyszeri díj fizetendő. \\
\hline MSBase & MSBase Alapítvány & Melbourne & 2004 & 58000 & Ingyenes \\
\hline
\end{tabular}

EDMUS = Európai SM Adatbázis; MSBase = sclerosis multiplex bázis; $S M=$ sclerosis multiplex 
2014 között zajlott az EUReMS-program [12], amelyben 13 európai országos vagy regionális SM-regiszter adatait harmonizálva, azokat egyetlen közös adatbázisba vonták össze. Célkitűzéseik közt az epidemiológiai kutatások, a gyógyszeres terápiák hosszú távú jellemzőinek elemzése, az egyes országok egészségügyi ellátásának értékelése és a betegcentrikus mutatók megismerése (életminőség, foglalkoztatottság, szocioökonómiai állapot) szerepelt. Mindezzel egy összeurópai SM-adatbázis alapjait tervezték létrehozni, a már múködő országos regiszterekre épülve, a program azonban egyelőre nem folytatódott.

Az alábbiakban néhány országos hatókörü, illetve két nemzetközi adatbázist mutatunk be, amelyek alapján tudományos publikációk is születtek, és így múködésük nemzetközileg is megismerhető.

A legrégebbi országos SM-regisztert 1956-ban alapították Dániában (Danish MS Registry [13]), és szinte minden SM-beteg adatát tartalmazza, aki 1948-ban életben volt vagy azóta született, valamint akinek a betegségét 1921 óta diagnosztizálták. Múködését kezdetben elsősorban az Amerikai és Dán Sclerosis Multiplex Egyesület (1966 óta), illetve 1986-tól az állami népegészségügyi büdzsé finanszírozza. Az adatokat a University of Southern Denmark gondozza, és kollaborációban országos lefedettségú, epidemiológiai kutatási projektekben is részt vesznek, az Állami Népegészségügyi Intézettel karöltve. Egy 2011. évi beszámoló szerint [14] az ország összes SM-betegének 91\%-a szerepel az adatbázisban, egy 2005. évi összesítés szerint több mint 20000 betegről volt feljegyzés. Az adatbázis rendszeresen frissül az immunmoduláns kezelésre vonatkozó adatokkal, amelyet egy másik rendszer, a Danish Multiple Sclerosis Treatment Register (DMSTR) [15] összesít 1996 óta. Különlegessége még, hogy állami engedéllyel a regiszter adatait más országos adatbázisokkal összekapcsolva számos egyéb információ is kideríthető a betegekről (például lakhely, társbetegségek, a halál ideje és oka, adózott jövedelem...), ami mélyreható epidemiológiai és egészség-gazdaságtani kutatásokra nyújt lehetőséget. E regiszter egyik hátránya, hogy a diagnózist követően a beteg aktuális állapotáról viszonylag kevesebb információt biztosít, mert az utánkövetés részletes adatait nem frissítik automatikusan, ezt azonban a kezelt betegekre vonatkozóan a DMSTR biztosítja [16].

Többéves szakmai egyeztetés és fejlesztés után, 2001ben indult el az országos svéd SM-regiszter (Swedish Multiple Sclerosis Registry, SMSreg [17]), amely 2004 óta webes alapú. Teljes mértékben államilag finanszírozott. Mind az ellátó neurológusok, mind a betegek részéről önkéntes az adatszolgáltatás, tehát a regisztráláshoz a betegek engedélyét kérik, és az bármikor visszavonható. A szoftveres felületen az ellátási helyen viszik be a friss klinikai adatokat, amelyeket a program rendszeresen és automatikusan továbbít az országos adatbázisba. Egy 2015. évi beszámoló alapján [18] közel 14500 beteg adatait gondozták, ami körülbelül 80\%-os lefedett- ségnek felel meg. Az adatok egy részét közvetlenül a betegek vihetik be, akár a szakrendelésen biztosított hozzáférés során, akár otthonukból saját biztonságos belépéssel - ez elsősorban a szubjektív mérőszámok (például életminőségi skálák) rögzítését teszi lehetővé. A klinikusok számára a szoftver alkalmazása nemcsak megkönnyíti egy adott beteg kórtörténetének átlátását, hanem a megadott paraméterek alapján segítséget nyújt klinikai döntéshozatalnál, például gyógyszerváltásnál. Az adott klinikus vagy centrum számos (20) szempont alapján kérheti a betegei összesítését, ezt grafikailag is megjelenítve. Egyes kiválasztott szempontok alapján végzett elemzések (például immunmoduláns kezelésben részesülő betegek aránya centrumonként) nyilvánosan vagy az állami felügyelet számára hozzáférhetők. Az adatbázisból végezhető tudományos kutatásokat külön etikai bizottság engedélyezi és felügyeli, részben a finanszírozó állami ellátó szempontjait is figyelembe véve (például egy témán ne dolgozzanak egyszerre többen). A folyamatos adatfrissítés nemcsak retrospektív, hanem prospektív jellegü kutatásokat is lehetővé tesz.

Az olasz SM-regiszter 2001-ben indult első változatának szoftveres hátterét az alább részletezett iMed-program biztosította, és a MSBase nemzetközi adatbázison belül létesítettek olasz alkohorszot, így a részvételt elsősorban tudományos publikációs társszerzőség motiválta. Csak 2015-ben indult el a független olasz SM-regiszter [19], amelyet az országos betegszervezet és a Bari Egyetem együttmúködésével hoztak létre és múködtetnek. A webalapú adatbázisba a betegek írásos beleegyezése után lehet rögzíteni adatokat. A 2018. évi közlés szerint körülbelül 54000 páciens adatait tartalmazza (50\% körüli lefedettség), 112 SM-centrum részvételével.

A német SM-regisztert 2001-ben hozták létre az országos SM-társaság (Deutsche MS Gesellschaft) égisze alatt [20]. A webes adatbázishoz közel 170 ellátó (egyetemi klinika, neurológiai osztály, rehabilitációs centrum és neurológus) járul hozzá, amelyeket az adatszolgáltatásra az motivál, hogy ez feltétele annak, hogy SM-centrumként elismerje őket a SM-társaság. A beteg beleegyezését követően a helyileg rögzített adatokat háromhavonta, pszeudonimizált formában töltik a központi regiszterbe, ahol rendszeres minőség-ellenőrzést és öszszefoglalást végeznek. A 2018. évi közlés szerint több mint 48000 fó szerepel benne [21].

Az Egyesült Királyságban is a SM-társaság felügyeli a regisztert [22], amely 2009-től próbaüzemben, 2014 óta éles módon múködik. Különlegessége, hogy nemcsak a regisztrált SM-centrumok és a központi állami egészségügyi felügyelőszerv szolgáltat hozzá adatokat, hanem egy webes felületen a SM-betegek maguk is bejelentkezhetnek, és rendszeresen információkat oszthatnak meg magukról és betegségükről, amelyek összefésülhetők az orvosi adatokkal. Anonimitásuk megőrzését segíti, hogy személyes azonosítóik és a betegséggel kapcsolatos adataik külön kerülnek tárolásra, és az ezekhez 
való hozzáférés is külön jogosultsághoz kötött. Több mint 17000 fó csatlakozott már az adatbázishoz.

Az Egyesült Államokban némileg hasonló elven múködik a NARCOMS- (North American Research Consortium on Multiple Sclerosis) regiszter [23], amelyet a SM Centrumok Egyesülete (Consortium of Multiple Sclerosis Centers) kezdeményezett és részben szponzorál. Emellett az országos SM-társaság, alapítványok és gyógyszercégek támogatják a múködését, amelyet a St. Louis-i székhelyű Washington Egyetem koordinál. A SM-betegek egy honlapon önként regisztrálhatnak és tölthetik ki rendszeresen a kérdőíveket betegségükról és életmódjukról (szükség esetén papírformában is beküldhetik). Közel 41000 résztvevő csatlakozott az elsősorban kutatási célokat szolgáló adatbázishoz, amelyből a beteg úgy profitál, hogy rendszeresen értesítik az induló tudományos tanulmányok indulásáról és eredményeiról.

Kanadában egy független nonprofit szervezet, a Kanadai Egészségügyi Információs Intézet (Canadian Institute for Health Information) üzemeltetett egy SM-regisztert (Canadian MS Monitoring System [24]) 2012 és 2016 között, azonban a csekély részvételi arány (3 SM-centrum) miatt ezt felfüggesztették. Országos lefedettségű kanadai SM-adatbázisról nincs tudomásunk.

A standardizált nemzetközi SM-adatbázis iránti igény már az 1990-es években megnyilvánult: 1990-ben Lyonban tartottak egy nemzetközi tudományos találkozót („Towards a European Database System for Multiple Sclerosis”) az Európai Gazdasági Közösség 11 országának részvételével. Itt fektették le az EDMUS (European Database System for Multiple Sclerosis [25]) standardizált tartalmát és formáját, alapul véve a már 1976 óta alkalmazott és fejlesztett lyoni SM-adatbázist [26]. Meghatározták többek között az egy betegről kötelezően és opcionálisan rögzíthető adatok halmazát, a tünetek egységes jelölését, a relapsus és a progresszió definícióját. Törekedtek nemzetközileg már széles körben elfogadott skálák (például Expanded Disability Status Scale, EDSS [27]) használatára, de a klinikai állapot részletesebb és egységesebb leírására ezek módosított változatát is bevezették (például úgynevezett EDMUS impairment scale [28]). A kezdetben csak angol nyelvú adatbázisba a kezelöorvos viheti be a beteg alapvető klinikai adatait, minden egyes megjelenéskor újabb lappal bővítve azt, név alapján tárolva az információt és jelszóval védve a hozzáférést. A rögzített adatok alapján a szoftver automatikusan jelzi, hogy például az aktuális diagnosztikai kritériumok teljesülnek-e vagy sem. A program lehetővé teszi anonimizált adatok kinyerését és megosztását. Az EDMUS-adatbázis kezelését, fejlesztését és koordinációját a Lyoni Egyetem Neurológiai Klinikája végezte és végzi azóta is, egy nemzetközi delegáltakból álló Felügyelőbizottság jóváhagyásával. Lyonból anyagi hozzájárulásért cserébe küldték el a telepíthető és modulokkal bővíthető programot kezdetben lemezen, és hasonló módon lehetett visszajuttatni hozzájuk a bevitt (anonimizált) adatokat. A tudományos együttmúködések sza- bályozására írásban lefektették, hogy egy adott beteg adatait csak a rögzítő személy engedélyével lehet felhasználni elemzésre vagy kutatásra, és ő automatikusan társszerzőként fog szerepelni egy esetleges publikációban. A koordináló centrum (Lyon) a részt vevő centrumok felől érkező kutatási terveket szakértői bizottság bevonásával jóváhagyja, és segíti azok megvalósulását.

Az EDMUS rendszert időközben továbbfejlesztették és kibővítették, jelenleg az EDMUS5 verzió él. A honlapról (www.edmus.org [25]) letölthető egy ingyenes demóverzió, amely időben és a betegszámot tekintve is korlátozottan használható. A teljes értékü szoftver online letöltése 200 euró átutalása után lehetséges, illetve a régebbi verziók frissítése is pénzbe kerül. A fizetendő díj felhasználónként értendő, de egy felhasználó több számítógépre is telepítheti a szoftvert. A program ma már több (európai) nyelven elérhető, a honlapról rendszeresen frissített bővítmények (például rögzíthető laborértékek listája) tölthetők le, és probléma vagy kérdés esetén itt vehető fel a kapcsolat a rendszer programozóival. A bevitt adatok könnyen exportálhatók anonim módon, és Excel-formátumban, majd online feltölthetők a közös adatbázisba.

A kutatási vagy betegkövetési projektek egy részét állami oldalról finanszírozzák (például a TYSEDMUS-kohorsz [29] elemzését a francia állami gyógyszerfelügyeleti szerv, az AFSSAPS kezdeményezésére indították a natalizumabbal kezelt páciensek követésére), továbbá a regionális betegellátási jellemzők megismerésében, standardok és ajánlások kidolgozásában is támaszkodnak a megyei (francia) egészségügyi hatóságokra és pénztárakra.

A 2017. márciusi adatok szerint világszerte 309 SMcentrum regisztrált felhasználóként 42 országból [25], de döntő többségükben európai államból. Franciaország 67 centrummal képviselteti magát (2016. évi adat), legalább 45000 regisztrált pácienssel, ami a becslések szerint a francia betegpopuláció közel fele, és ezzel a franciaországi SM-regiszterként is múködik. Már 2003-ban megalapították a Francia SM-figyelő Programot (Observatoire Français de la Sclérose en Plaques, OFSEP [30]), amely - elsősorban az EDMUS-adatok alapján - évente beszámol a betegség országos mutatóiról, ideértve az előfordulását, a kezelést és a javasolt változtatásokat az ellátásban. Mindez a Francia Neurológiai Társaság égisze alatt, és 2011 óta a Felsőoktatásért és Kutatásért Felelős Minisztérium anyagi támogatásával zajlik.

$\mathrm{Az}$ úgynevezett MSBase Registry (www.msbase.org [31]) múködtetője egy ausztrál székhelyü nonprofit szervezet, amely 2004-ben jött létre. Alapítványukat magánszemélyek, betegszervezetek és gyógyszercégek is támogatják, közvetve finanszírozva a nemzetközi adatbázis kiépítését és múködtetését, de akár egy-egy kiválasztott tudományos projektet célzottan is támogathatnak. Küldetésüknek tartják a neuroimmunológiai betegségek, például a SM területén végzett kollaborációs kutatások elősegítését. Szerkezetéből adódóan elsősorban 
beavatkozással nem járó, megfigyeléses jellegű (főként epidemiológiai, illetve „real-world” gyógyszerhatékonysági) kutatásokat tesz lehetővé, ilyen témát bármely résztvevő javasolhat, és azt a Tudományos Bizottság hagyja jóvá.

A regiszter angol nyelvü. Ingyenes online regisztrációval csatlakozhat bármely neurológus vagy neurológiai intézmény, aki/amely a központi adatellenőrzés, illetve a Csatlakozási Nyilatkozat aláírása után teljes értékű használójává válik. Amennyiben a regisztráció egy SM-centrumra vonatkozik, lehetőség van több kezelőorvos részvételére is.

$\mathrm{Az}$ adatrögzítés két formában történhet: a régebb óta múködő megoldás, hogy egy honlapról ingyenesen letölthető szoftvert (iMed) telepítve a helyi számítógépre és abba jelszóval belépve a saját számítógépen készül egy adatbázis. Ebból bármikor néhány kattintással kinyerhetők az adatok anonimizált formában, illetve feltölthetők az online közös adatfelhóbe a MSBase honlapján keresztül. Ezt a szoftvert rendszeresen fejlesztik és frissítik. Emellett 2017 óta közvetlenül online is rögzíthetők a betegadatok, amelyek így bárhonnan hozzáférhetők az orvos számára, és az anonimizált formát a rendszer automatikusan tölti a közös adattárba.

A jelszóval védett online felületen lehetőség nyílik saját, specifikus témájú vagy regionális alprojektet hirdetni (például Hungarian Natalizumab Cohort [32]), illetve már futó alprojekthez csatlakozni. A meghirdetéshez a Tudományos Bizottság engedélye kell, a csatlakozáshoz pedig az alprojekt vezetőjének jóváhagyása. Ezt követően a csatlakozó centrum betegei közül - automatikusan vagy manuálisan - kiválogatják a meghatározott paramétereknek megfelelőket, és egy közös betegkohorszot hoznak létre, amelyet minden résztvevő centrum lát.

A honlap közlése szerint jelenleg 36 országból több mint 58000 beteg adatait rögzítették, ebből Magyarország 291 beteggel vesz részt. Az adatok feldolgozásából csak 2017-ben 10 magas színvonalú tudományos publikáció született [33], emellett számtalan kongresszusi előadás és poszter. Az önkéntes adatrögzítésre (amely párhuzamosan zajlik a rutin-betegellátás dokumentálásával, azt tehát nem helyettesíti) azzal motiválják a kezelóorvosokat, hogy a felhasználóbarát szoftverrel igyekeznek megkönnyíteni az adott beteg történetének áttekintését, valamint azzal, hogy ha egy tudományos publikációhoz a centrum által regisztrált betegek közül kellően soknak az adatát használták fel, az automatikusan társszerzőséggel jár.

\section{Gyógyszeripari cégek által létrehozott adatbázisok}

A multinacionális, elsősorban gyógyszeripari cégeknek anyagi érdekük a lehető legtöbb információt megtudni a saját, illetve versenytársaik termékeiról, azok hatékonyságáról, mellékhatásairól, az ezt alkalmazó betegek preferenciáiról. Jogszabályok azonban előírják (elsősorban az adatvédelemre vonatkozó passzusok), hogy a kényes adatnak minősülő információkat (ilyenek az egészségi állapotra vonatkozók) fokozott védelem illeti meg, és így természetesen nem közölhetők harmadik féllel, különösen nem gazdasági szereplővel. Ez az ellentmondás szigorú szabályok lefektetésével azonban feloldható, és erre több múködő példa is hozható (lásd később).

A gyógyszercég ilyenkor az Országos Tudományos és Kutatásetikai Bizottsághoz (TUKEB) nyújt be egy - szakmailag kellően megalapozott - kutatási vagy betegkövetési tervet, megindokolva, hogy milyen (tudományos vagy klinikai jellegü) kérdésre keresik a választ, pontosan milyen paramétereket kívánnak rögzíteni, és az adatbiztonság milyen garanciáit biztosítják. Kedvező elbírálás esetén a cég (vagy egy általa megbízott közvetítő cég) megkeresi az ilyen betegeket ellátó, illetve gondozó egészségügyi szolgáltatókat, és az intézettel, valamint a beteggel közvetlen kapcsolatban álló orvosokkal szerződést köt az adatszolgáltatásra. Az intézményi etikai bizottság értesítése is szükséges. A szerződés alapján az előzetesen megadott kritériumoknak megfelelő beteg részletes felvilágosítása és írásos beleegyezése után a kérdéses paramétereket a kezelőorvos (vagy az ő megbízott adminisztrátora) anonimizált formában rögzíti a cég által fejlesztett és üzemeltetett - jellemzően jelszóval védett online - adatbázisban. Ezért az adatszolgáltatásban részt vevő személyzet és az intézmény is anyagi ellenszolgáltatást kap, a szerződésnek megfelelően. Az adatok helyességét és teljességét rendszerint egy, a finanszírozó gyógyszercég által megbízott, erre szakosodott úgynevezett Contract Research Organisation (CRO) vállalkozás ellenőrzi rendszeresen. A bevitt adatok felett a megbízó cég rendelkezik, feldolgozásuk és közreadásuk csak az ő írásos engedélyével történhet, tehát megismerhetőségük igen korlátozott. A beteg természetesen indoklás nélkül, bármikor visszavonhatja az adatai kezeléséhez adott beleegyezését.

Ilyen adatbázis építésére számtalan nemzetközi és hazai példa van, gyakorlatilag az összes gyógyszerkipróbálási vagy -utánkövetési vizsgálat ilyen. Ezáltal teljesebb kép nyerhető a kérdéses betegpopulációról, a készítmény hatékonyságáról és mellékhatásairól. Egy nemzetközi SM-kongresszuson bemutatott poszter szerint [34] például a magyar fingolimod-adatbázis 475 beteg adatait tartalmazza. A projekt célja a kezelés hatékonyságának és mellékhatásainak megítélése ötéves utánkövetés végén. Mivel azonban mind a beteg, mind a kezelőorvos részérôl önkéntes a közremúködés, a regiszter valószínúleg nem tartalmazza a fingolimoddal kezelt összes beteget.

\section{Magyar adatbázisok}

Az egészségügyi finanszírozó, a Nemzeti Egészségbiztosítási Alapkezelő a kötelező jelentések révén mind a járó-, mind a fekvőbeteg-ellátásban részesülő SM-páciensekről információt kap (beavatkozások, diagnózisok kódjai), továbbá az Elektronikus Egészségügyi Szolgáltatási Tér 
bevezetésével a részletes zárójelentés és ambulánslap is automatikus feltöltésre kerül az e-receptekkel együtt. A szöveges formában tárolt adatok feldolgozása azonban nehézkes, erőforrás-igényes. Az információ az állami hivatal gondozása alá kerül, és az országosan összesített adatok kutatási célú felhasználása csak korlátozottan, az Alapkezelő beleegyezésével és felügyeletével, továbbá bizonyos esetekben anyagi ellenszolgáltatásért cserében lehetséges.

Számos magyar SM-centrum is vezet adatokat a betegeiről, de - vélhetően erőforráshiány miatt - csak kevésbé strukturált módon (például Excel-táblázat) és a napi betegellátási rutinra támaszkodva. Megjegyzendő, hogy a 2000-es évek elejéig a centrumoknak havonta kötelező volt jelenteniük a Jahn Ferenc Kórházban kijelölt felelősnek az általuk gondozott, immunmoduláns kezelésben részesülő betegek teljes listáját (ennek különösen akkor volt még jelentősége, amikor például az interferonkezelésre országos várólista létezett). Ez a kötelezettség azonban késôbb, a terápiás paletta és az erre fordított büdzsé növekedésével megszűnt. Hasonlóképpen, a natalizumabkezelés megjelenésekor az ennek alkalmazására kijelölt centrumok egy országos szakmai egyeztetés értelmében e betegek adatait, állapotát az iMed-szoftver segítségével a MSBase egyik alprojektjében (úgynevezett Hungarian Natalizumab Cohort) rögzítették. Az egyre több csatlakozó centrum és megnövekedett betegszám mellett, továbbá a szakmai felügyelet és motiváció hiánya miatt (az adatszolgáltatás ugyanis önkéntessé vált) ezen adatbázis néhány év után csonka maradt.

Jelenleg tehát nem létezik egységes, országos lefedettségú magyar SM-adatbázis, azonban ennek megteremtése a nemzetközi trendeknek megfelelően a Magyar Neuroimmunológiai Társaság kitűzött célja. Elnökségi döntés született arról 2017-ben, hogy hazánkban a Szegedi Tudományegyetem Neurológiai Klinikáján már használt SM-regisztert fogjuk bevezetni, amelyről részletes ismertetés jelent meg 2017-ben [5]. E regiszterhez jelenleg önként csatlakozhatnak a SM-centrumok, ennek előfeltétele a helyi intézményi etikai bizottság engedélye.

\section{Következtetések}

A SM-betegek adatainak helyi gyưjtése és rögzítése évtizedekre nyúlik vissza, azonban az országos lefedettségú regisztereket fő́ként az elmúlt 15 évben indították el, felismerve azok jelentőségét. A már múködő adatbázisok sokfélék, így több szempont szerint csoportosíthatók, például a fó finanszírozó alapján (állami forrás, nonprofit SM-szervezet, tudományos egyesület, gyógyszeripar) vagy az adatközlés motivációja szerint (elö́rás, klinikai ellátásban segédlet, tudományos publikációs lehetőség). A regiszterek manapság anonimizáltak vagy pszeudonimizáltak, továbbá webalapúak, megteremtve ezzel az adatok könnyü hozzáférhetőségének, naprakészen tartásának, gyors feldolgozásának lehetőségét. Bizonyos adatbázisokhoz maguk a betegek is csatlakozhatnak, és információkat rögzíthetnek bennük, másokat csak az egészségügyi személyzet frissít, többnyire a beteg írásos beleegyezését követően. Az országokon átívelö, nemzetközi regiszterek az adatmennyiség növelése révén bővebb tudományos forrást jelentenek, amit az egységesített adatrögzítés révén valósítanak meg. Mindezen szempontokat és a hazai realitásokat figyelembe véve készítettük el egy helyi SM-regiszter modelljét [35], amely kihasználja a korszerü informatikai lehetőségeket. A jövőben azonban valószínúleg egyre nagyobb szerep jut a keletkező - akár egészségügyi - információk feldolgozásában az úgynevezett adattónak (data lake) [36], amelybe a nyers, félig és teljesen strukturált adatok vegyesen kerülnek be. Ez a 'big data' projektek nélkülözhetetlen eleme, amelybe a különböző forrásokból származó adatok eredeti formátumukban kerülnek be. Segítségével az adatokat nem kell egy előre definiált adattárban elhelyezni vagy átalakítani, ezáltal azonnal hozzáférhetők, amivel idő és költség takarítható meg a feldolgozásuk során, emellett lehetőség nyílik az utólagos, újabb és újabb szempontok szerinti elemzésükre. Az egészségügyi adattó hazai prototípusának kidolgozása és megvalósítása a Pécsi Tudományegyetem és az E-Group ICT Zrt. konzorciális együttmúködésével folyamatban van (InnoHealth DataLake GINOP-2.2.115-2017-00067).

Anyagi támogatás: A tanulmány alapjául szolgáló kutatást az Emberi Erőforrások Minisztériuma által meghirdetett Felsőoktatási Intézményi Kiválósági Program támogatta, a Semmelweis Egyetem neurológiai tématerületi programja keretében.

Szerzôi munkamegosztás: I. A., S. M., T. N.: Az adatbázis létrehozása. Sz. M., M. P., B. D.: A koncepció kidolgozása. B. D., I. A., S. M., T. N.: A kézirat megszövegezése és a táblázat elkészítése. A cikk végleges változatát valamennyi szerző elolvasta és jóváhagyta.

Érdekeltségek: A szerzőknek nincsenek érdekeltségeik a cikkel kapcsolatban.

\section{Köszönetnyilvánítás}

Köszönetünket fejezzük ki a Pázmány Péter Katolikus Egyetem Jog- és Államtudományi Kara munkatársainak az adatvédelem és adathasználat jogi szempontjaival kapcsolatos eszmecseréért, valamint a Semmelweis Egyetem Egészségügyi Közszolgálati Karának az anyagi támogatásért.

\section{Irodalom}

[1] Feigin VL, Alemu Abajogir A, Hassen Abate K., et al, for GBD 2015 Neurological Disorders Collaborator Group. Global, regional, and national burden of neurological disorders during 1990-2015: a systematic analysis for the Global Burden of Disease Study 2015. Lancet Neurol. 2017; 16: 877-897. 
[2] Gustavsson A, Svensson M, Jacobi F, et al. Cost of disorders of the brain in Europe 2010. Eur Neuropsychopharmacol. 2011; 21: 718-779.

[3] Bencsik K, Rajda C, Klivényi P, et al. The prevalence of multiple sclerosis in the Hungarian city of Szeged. Acta Neurol Scand. 1998; 97: 315-319.

[4] Zsiros V, Fricska-Nagy Z, Füvesi J, et al. Prevalence of multiple sclerosis in Csongrád County, Hungary. Acta Neurol Scand. 2014; 130: 277-282.

[5] Bencsik K, Sandi D, Biernacki T, et al. The Multiple Sclerosis Registry of Szeged. [A Szegedi Sclerosis Multiplex Regiszter.] Ideggyógy Sz. 2017; 70: 301-306. [Hungarian]

[6] Kurtzke JF. An evaluation of the geographic distribution of multiple sclerosis. Acta Neurol Scand. 1966; 42(Suppl 19): 91-117.

[7] Ebers GC, Sadovnick AD. The geographic distribution of multiple sclerosis: a review. Neuroepidemiology 1993; 12: 1-5.

[8] Wikström J. Studies on the clustering of multiple sclerosis in Finland II: microepidemiology in one high-risk county with special reference to familial cases. Acta Neurol Scand. 1975; 51 : 173183.

[9] Doolittle TH, Myers RH, Lehrich JR, et al. Multiple sclerosis sibling pairs: clustered onset and familial predisposition. Neurology 1990; 40: 1546-1552.

[10] Flachenecker P, Buckow K, Pugliatti M, et al. Multiple sclerosis registries in Europe - results of a systematic survey. Mult Scler. 2014; 20: 1523-1532.

[11] European Multiple Sclerosis Platform. The voice of people with MS in Europe. Available from: http://www.emsp.org/ [accessed: July 16, 2018].

[12] European Register for Multiple Sclerosis. Available from: http:// www.emsp.org/projects/eurems/ [accessed: July 16, 2018].

[13] Rigshospitalet. The Danish Multiple Sclerosis Registry. Available from: https://www.rigshospitalet.dk/english/departments/ neuroscience-centre/department-of-neurology/research/thedanish-multiple-sclerosis-registry/Pages/default.aspx [accessed: July 16, 2018].

[14] Brønnum-Hansen H, Koch-Henriksen N, Stenager E. The Danish Multiple Sclerosis Registry. Scand J Public Health 2011; 39(Suppl 7): 62-64.

[15] Magyari M, Koch-Henriksen N, Sørensen PS. The Danish Multiple Sclerosis Treatment Register. Clin Epidemiol. 2016; 549552

[16] Koch-Henriksen N, Magyari M, Laursen B. Registers of multiple sclerosis in Denmark. Acta Neurol Scand. 2015; 132(Supp 199): 4-10

[17] Andersen O. From the Gothenburg cohort to the Swedish multiple sclerosis registry. Acta Neurol Scand Suppl. 2012; 126(S195): 13-19

[18] Hillert J, Stawiarz L. The Swedish MS registry - clinical support tool and scientific resource. Acta Neurol Scand. 2015; 132(Suppl 199): 11-19.

[19] The Italian Multiple Sclerosis Register - Translating research into health. Available from: https://registroitalianosm.it/en/ [accessed: July 16, 2018].
[20] Flachenecker P, Stuke K, Elias W, et al. Multiple Sclerosis Registry in Germany - Results of the Extension Phase 2005/2006 Dtsch Arztebl Int. 2008; 105: 113-119.

[21] MS Forschungs- und Projektentwicklungs-gGmbH. Das MSRegister. Available from: https://www.msregister.de/ms-register/das-ms-register/ [accessed: July 16, 2018].

[22] MS Register. Help make sense of MS. Available from: https:// www.ukmsregister.org [accessed: July 17, 2018].

[23] NARCOMS Registry for Multiple Sclerosis. Available from: https://www.narcoms.org/ [accessed: July 17, 2018].

[24] Canadian Multiple Sclerosis Monitoring System Metadata. Available from: https://www.cihi.ca/en/canadian-multiple-sclerosismonitoring-system-metadata [accessed: July 17, 2018].

[25] EDMUS. Your personal MS database. Available from: https:// www.edmus.org/ [accessed: July 17, 2018]

[26] Confavreux C, Compston DA, Hommes OR, et al. EDMUS, a European database for multiple sclerosis. J Neurol Neurosurg Psychiatry 1992; 55: 671-676.

[27] Kurtzke JF. Rating neurologic impairment in multiple sclerosis: an expanded disability status scale (EDSS). Neurology 1983; 33: 1444-1452.

[28] The EDMUS Grading Scale (EGS/DSS). Available from: https://www.edmus.org/en/proj/ms_egs.html [accessed: July $17,2018]$

[29] Étude TYSEDMUS. Available from: https://www.edmus.org/ fr/studies/tysedmus.html [accessed: July 17, 2018].

[30] Observatoire Français de la Sclérose en Plaques. Available from: http://www.ofsep.org/en/ [accessed: July 17, 2018].

[31] MSBase. Neuro-Immunology Registry. Available from: www. msbase.org [accessed: July 17, 2018].

[32] Hungarian natalizumab cohort. MSBase sub-studies. Available from: https://www.msbase.org/sub-studies/ [accessed: July $17,2018]$.

[33] Kalincik T, Manouchehrinia A, Sobisek L, et al. Towards personalized therapy for multiple sclerosis: prediction of individual treatment response. Brain 2017; 140: 2426-2443.

[34] Bencsik K, Biernacki T, Füvesi J, et al. Interim data from the Hungarian fingolimod registry (CFTY720DHU01). EP1696. ECTRIMS Online Library 2017; 199716.

[35] Iljicsov A, Simó M, Tegze N, et al. Multiple sclerosis in central Hungary: experiences and future possibilities of developing a local database. [Sclerosis multiplex a közép-magyarországi régióban: a helyi adatbázisfejlesztés tapasztalatai és jövőbeli lehetőségei.] Orv Hetil. 2019; 160(4): 131-137.

[36] Inmon B. Data lake architecture: designing the data lake and avoiding garbage dump. Technics Publications, Basking Ridge, NJ, 2016.

(Bereczki Dániel dr., Budapest, Balassa u. 6., 1083 e-mail: bereczki.daniel@med.semmelweis-univ.hu)

A cikk a Creative Commons Attribution 4.0 International License (https://creativecommons.org/licenses/by/4.0/) feltételei szerint publikált Open Access közlemény, melynek szellemében a cikk bármilyen médiumban szabadon felhasználható, megosztható és újraközölhetö, feltéve, hogy az eredeti szerző és a közlés helye, illetve a CC License linkje és az esetlegesen végrehajtott módositások feltüntetésre kerülnek. (SID_1) 